\title{
Rainwater quality improvement using zeolite, activated carbon, limestone and preheated $400^{\circ} \mathrm{C}$ limestone
}

\author{
Meilani $^{1, *}, S$. Syafalni ${ }^{2}$, Yulianto Santoso ${ }^{1}$, and Gorga Green Malau ${ }^{1}$ \\ ${ }^{1}$ Civil Engineering Department, Bina Nusantara University, 11480 Jakarta, Indonesia \\ ${ }^{2}$ Civil Engineering Department, National Institute of Sciences and Technology, 12640 Jakarta, Indonesia
}

\begin{abstract}
Resources of clean water have decreased significantly in recent years, one of the reasons is water pollution. Utilization of rainwater as clean water resource is among the best option, especially in big cities like Jakarta. Excessive rainwater during wet season can be saved and used as the source of clean water during dry seasons. However, rainwater contains some pollutants, thus suitable treatment method should be utilized to improve its quality as clean water for daily needs. This study compared the effectiveness of zeolite, limestone, activated carbon and preheated $400^{\circ} \mathrm{C}$ limestone as additive to improve the rainwater quality. Results show that both limestone and preheated $400^{\circ} \mathrm{C}$ limestone improve all the parameters observed, meanwhile both activated carbon and zeolite had shown to have detrimental effect on water conductivity.
\end{abstract}

\section{Introduction}

Although the earth surface is covered almost $70 \%$ by water, but only approximately $3 \%$ of water can be used [1]. People in Indonesia, mostly in large city like Jakarta, using ground water as one of the water resources to fulfill their daily needs [2]. The rainwater has not been an option yet for people in Jakarta while there are many advantages that can be obtained from rainwater [3].

Rainwater in Indonesia contains acid and the $\mathrm{pH}$ level is 5.6 [4]. It needs treatment so it can be used for daily needs.

Water conductivity, $\mathrm{pH}$ and TDS are the water characteristics to be observed. Water conductivity shows the ability of water to transmit electricity [5]. Water $\mathrm{pH}$ is indicator of level of acidity and basicity of water [6]. Water TDS is the total amount of ions, including minerals, salts or metals dissolved in the water [7].

\section{Experimental details}

The first stage of experiment was to determine the material used as filter. Zeolite, activated carbon, limestone $[8,14-15]$ and preheated $400^{\circ} \mathrm{C}$ limestone were used to improve the rainwater quality.

Zeolite was used as an absorbent for reducing water hardness[9]. Activated carbon removed water odor and taste, absorbed water chlorine and purified water [10]. Limestone purified water and stabilized water $\mathrm{pH}$. Limestone $(\mathrm{CaCO} 3)$ was heated to produce Calcium Oxide $(\mathrm{CaO})$ to reduce the water hardness [11].

Zeolite was soaked using $1 \mathrm{~N} \mathrm{NaCl}$ for 24 hours.Activated carbon was soaked using $1 \mathrm{~N} \mathrm{NaOH}$ for
24 hours. Then both were dried using an oven with a temperature of $115^{\circ} \mathrm{C}$ for 24 hours $[12,13]$.

Limestone was heated gradually. The temperature was increased by $100^{\circ} \mathrm{C}$ every 15 minutes, starting from $200^{\circ} \mathrm{C}$ and ended at $400^{\circ} \mathrm{C}$ [14].

Each of materials were categorized into 3 different sizes: large size (materials passing sieve number 4 and retained by sieve number 8 ), medium size (materials passing sieve number 8 and retained by sieve number 10 ) and small size (materials passing sieve number 10 and retained by sieve number 16) $[14,15]$.

Each variation of size divided to 10 weight of variation $(0.5 \mathrm{~g}, 1 \mathrm{~g}, 3 \mathrm{~g}, 5 \mathrm{~g}, 7 \mathrm{~g}, 10 \mathrm{~g}, 15 \mathrm{~g}, 20 \mathrm{~g}, 25 \mathrm{~g}$, $30 \mathrm{~g})$. This experiment was conducted 3 times for each variation.

\section{Results}

\subsection{Conductivity}

Zeolite increased the water conductivity as shown in Fig.1. The results of water conductivity using zeolite varied from 0.01 to 0.25 . Medium sized zeolite resulted the highest conductivity compared to the other sizes. Large sized zeolite and small sized zeolite resulted the similar effect on water conductivity. The addition of zeolite weight into the water increased the value of water conductivity.

As shown in Fig.2, the water conductivity increased significantly because of activated carbon. The results of water conductivity using activated carbon varied from 0.03 to 1.29 . The results showed the size of activated carbon affected the water conductivity. Large sized 
activated carbon resulted the highest conductivity compared to the other sizes. Small sized activated carbon resulted the lowest conductivity compared to the other sizes. The addition weight of large sized activated carbon increased the value of water conductivity. When the weight of medium sized activated carbon were $0.5 \mathrm{~g}$, $1 \mathrm{~g}, 3 \mathrm{~g}, 5 \mathrm{~g}, 7 \mathrm{~g}, 10 \mathrm{~g}, 15 \mathrm{~g}$ and $20 \mathrm{~g}$, the value of water conductivity gradually increased. But when the weight of medium sized activated carbon was $25 \mathrm{~g}$, the value of water conductivity decreased. The value of water conductivity increased again when the weight of medium sized activated carbon was $30 \mathrm{~g}$. The water conductivity of small sized activated carbon kept increasing until the weight of $25 \mathrm{~g}$, and it decreased when the weight was 30 g.

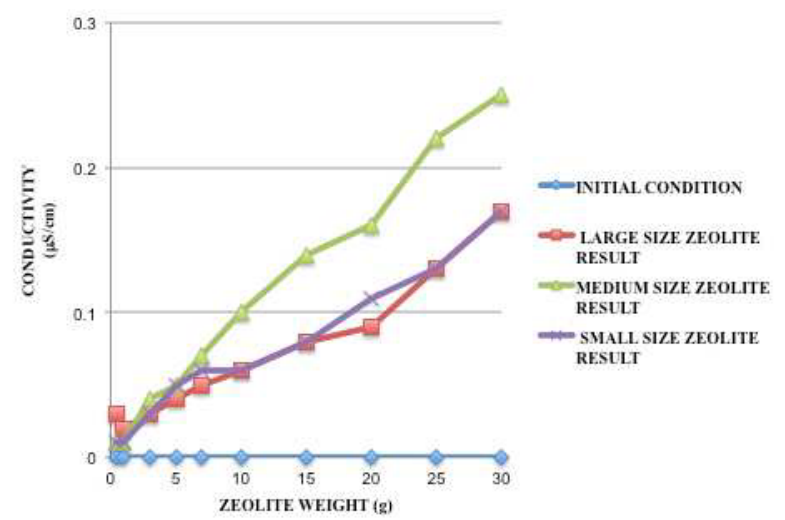

Fig. 1. Water conductivity using zeolite

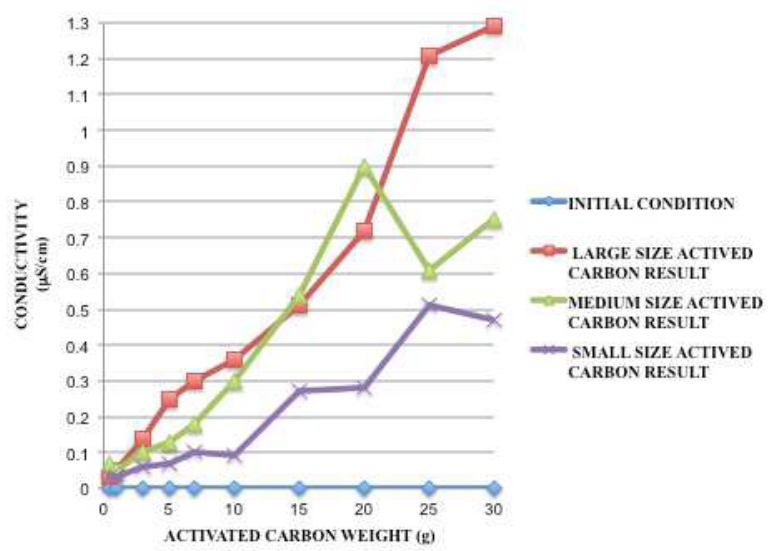

Fig. 2. Water conductivity using activated carbon

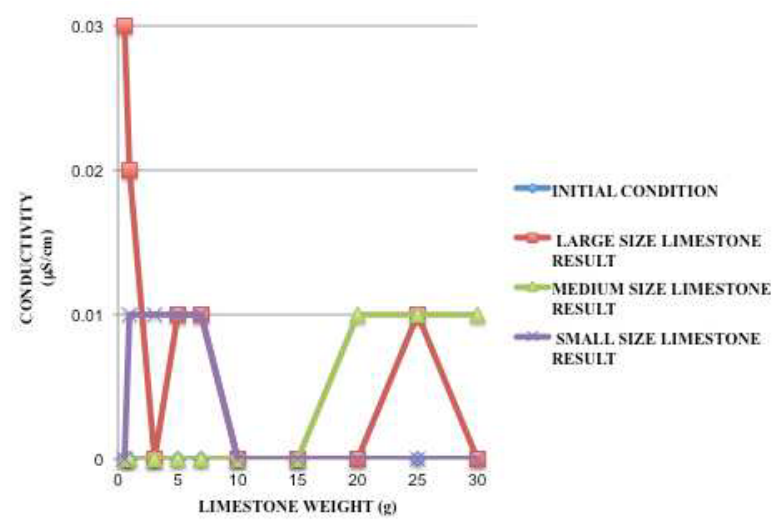

Fig. 3. Water conductivity using limestone
Both preheated $400^{\circ} \mathrm{C}$ limestone and limestone, didn't affect much on the water conductivity. It can be seen at Fig.3 and Fig.4. As shown in Fig.3., the results of water conductivity using limestone varied from 0.00 to 0.03 . The large sized limestone with weight less than 3 grams resulted the highest conductivity compared to the other sizes and weights.

As shown in Fig. 4, the results of water conductivity using preheated $400^{\circ} \mathrm{C}$ limestone varied from 0.00 to 0.02 . The small sized preheated $400^{\circ} \mathrm{C}$ limestone with weight less than 3 grams resulted the highest conductivity compared to the other sizes and weights.

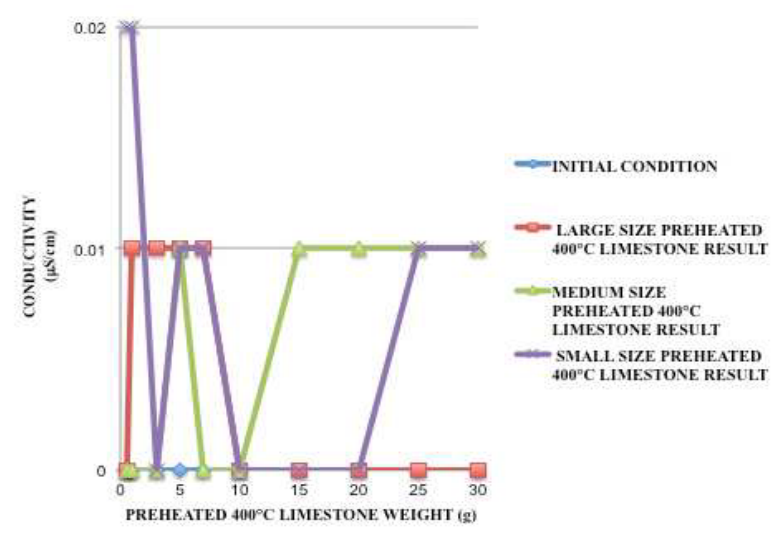

Fig. 4. Water conductivity using preheated $400^{\circ} \mathrm{C}$ limestone

\subsection{Water $\mathrm{pH}$}

The increasing results of water $\mathrm{pH}$ using zeolite varied between 0.37 and 2.31 point higher from the initial condition. Large sized zeolite and medium sized zeolite resulted the similar effect on water $\mathrm{pH}$ but the large sized zeolite resulted the highest water $\mathrm{pH}$ compared to the other sizes, as shown in Fig.5. The addition weight of large and medium sized zeolite increased the value of water $\mathrm{pH}$.

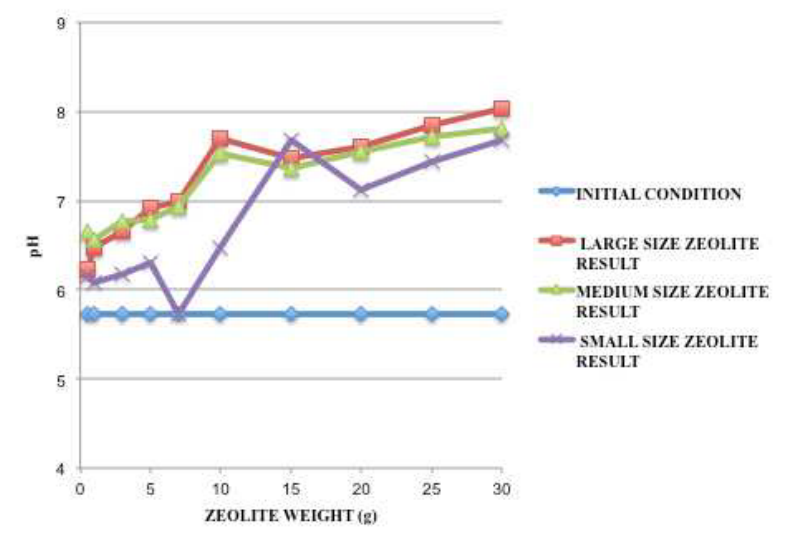

Fig. 5. Water $\mathrm{pH}$ using zeolite

The increasing results of water $\mathrm{pH}$ using activated carbon varied between 0.58 and 2.32 point higher from the initial condition. The large sized activated carbon resulted the highest water $\mathrm{pH}$ compared to the other sizes, as shown in Fig.6. 


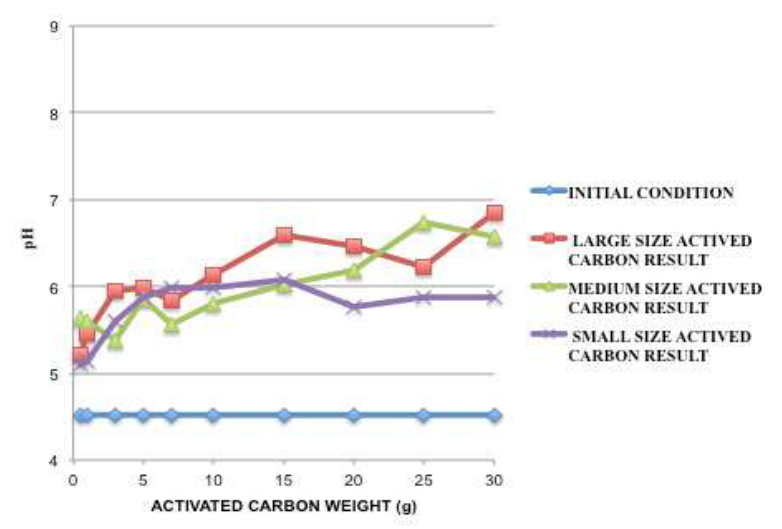

Fig. 6. Water $\mathrm{pH}$ using activated carbon

The increasing results of water $\mathrm{pH}$ using limestone varied between 1.01 and 2.18 point higher from the initial condition. The small sized limestone resulted the lowest water $\mathrm{pH}$ and the large sized limestone resulted the highest water $\mathrm{pH}$ compared to the other sizes, as shown in Fig. 7.

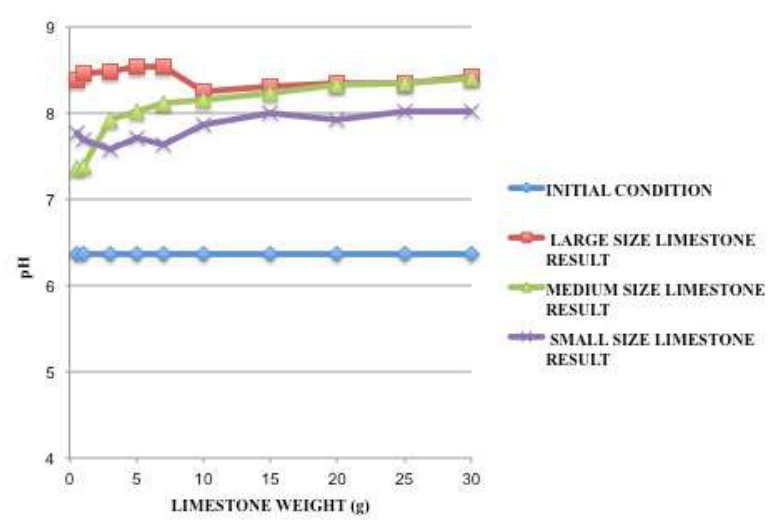

Fig. 7. Water $\mathrm{pH}$ using limestone

The increasing results of water $\mathrm{pH}$ using preheated $400^{\circ} \mathrm{C}$ limestone varied between 1.06 and 2.64 point higher from the initial condition. The large sized preheated $400^{\circ} \mathrm{C}$ limestone resulted the lowest water $\mathrm{pH}$ and the small sized preheated $400^{\circ} \mathrm{C}$ limestone resulted the highest water $\mathrm{pH}$ compared to the other sizes, as shown in Fig.8.

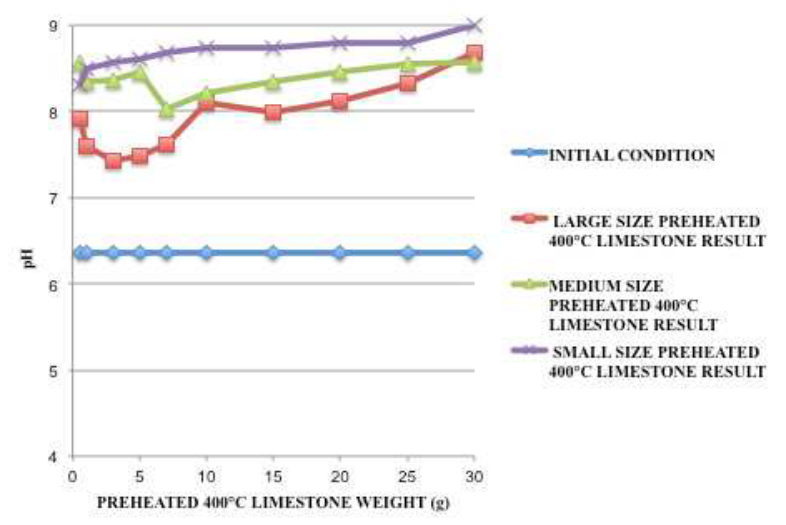

Fig. 8. Water $\mathrm{pH}$ using preheated $400^{\circ} \mathrm{C}$ limestone

\subsection{Water TDS}

As shown in Fig.9, the results of water TDS using zeolite varied between 0.00 and 0.12 . Medium sized zeolite resulted the highest TDS compared to the other sizes. Large and small sized zeolite resulted the similar effect on water TDS.

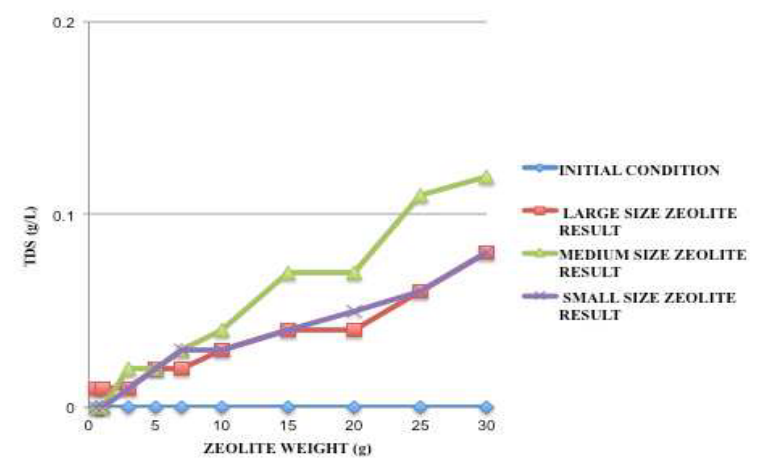

Fig. 9. Water TDS using zeolite

As shown in Fig.10, the water TDS increased because of activated carbon. The results of water TDS using activated carbon varied from 0.01 to 0.64 . The large sized activated carbon resulted the highest water TDS compared to the other sizes. The small sized activated carbon resulted the lowest water TDS compared to the other sizes.

The results showed the size and the weight of activated carbon affected the water TDS. The addition weight of large sized activated carbon increased the value of water TDS. When the weight of medium sized activated carbon were $0.5 \mathrm{~g}, 1 \mathrm{~g}, 3 \mathrm{~g}, 5 \mathrm{~g}, 7 \mathrm{~g}, 10 \mathrm{~g}, 15 \mathrm{~g}$ and $20 \mathrm{~g}$, the value of water TDS gradually increased. But when the weight of medium sized activated carbon was $25 \mathrm{~g}$, the value of water TDS decreased. The value of water TDS increased again when the weight of medium sized activated carbon was $30 \mathrm{~g}$. The water TDS of small sized activated carbon kept increasing until the weight of $25 \mathrm{~g}$, and it decreased when the weight was 30 g.

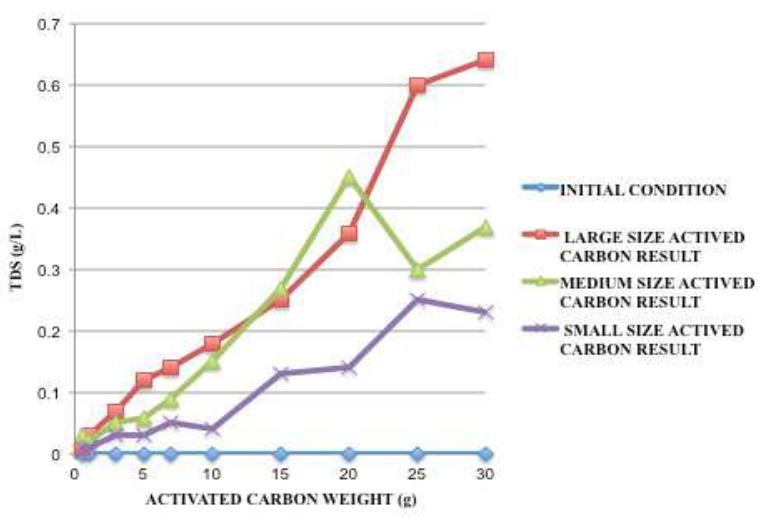

Fig. 10. Water TDS using activated carbon

As shown in Fig. 11 and Fig. 12, both preheated $400^{\circ} \mathrm{C}$ limestone and limestone, didn't affect much to the water TDS. The results of water TDS using limestone and preheated $400^{\circ} \mathrm{C}$ limestone varied from 0.00 to 0.01 . The 
large sized preheated limestone with weight less than 3 grams resulted the highest TDS compared to the other sizes and weights. The medium and small sized limestone had shown no effect on the water TDS, as shown in Fig. 11.

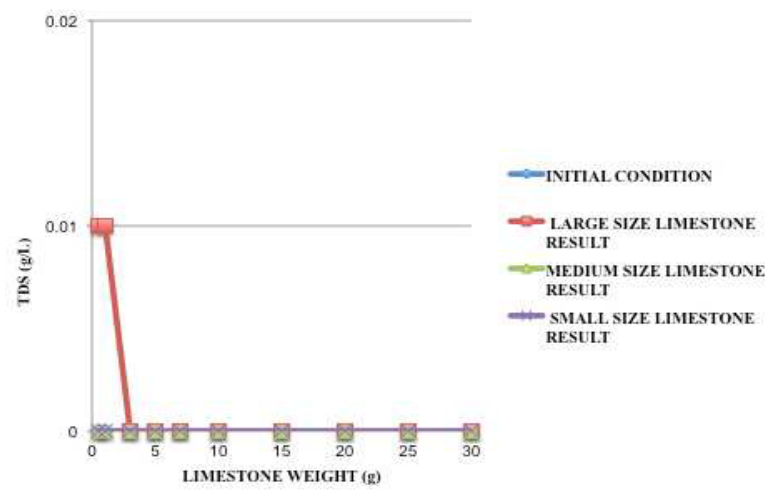

Fig. 11. Water TDS using limestone

The small and large sized preheated $400^{\circ} \mathrm{C}$ limestone had shown the similar effect on the water TDS. The small and large sized preheated $400^{\circ} \mathrm{C}$ limestone with weight less than 3 grams resulted the highest water TDS compared to the other sizes and weights. The medium sized preheated $400^{\circ} \mathrm{C}$ limestone had shown no effect on the water TDS, as shown in Fig. 12.

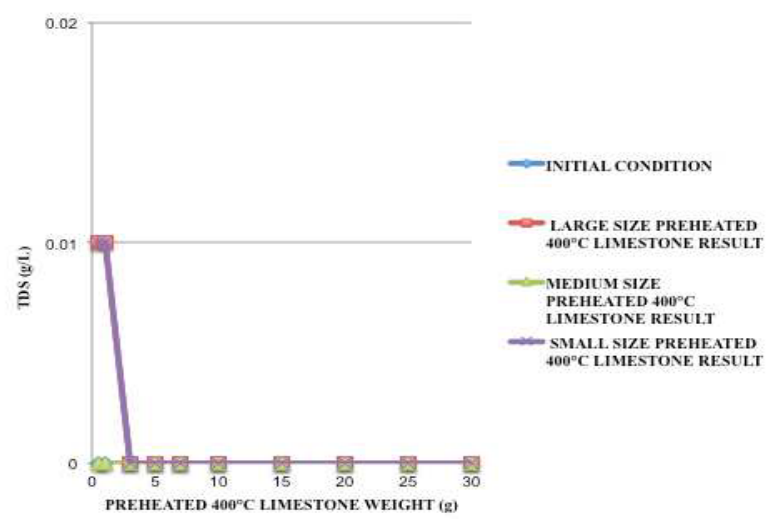

Fig. 12. Water TDS using preheated $400^{\circ} \mathrm{C}$ limestone

\section{Conclusion}

From the results, it concluded that both limestone and preheated $400^{\circ} \mathrm{C}$ Limestone were found to improve all parameters observed.

The small sized preheated $400^{\circ} \mathrm{C}$ Limestone was found to be the best material to obtain low water conductivity, higher $\mathrm{pH}$ and lower water TDS values.
Both activated carbon and zeolite had shown to have detrimental effect on water conductivity.

Activated carbon had shown similar effect on water conductivity and TDS.

This research was funded by Ministry of Research, Technology and Higher Education of the Republic of Indonesia (contract number: 791/K3/KM/SPK.LT/2016).

\section{References}

1. Information from http://savethewater.org/ education- resources/water-facts (August 2016)

2. Information from http://www.ipsnews.net/2000/02/ environment-indonesia-drowing-in-water-woes (August 2016)

3. Information from http://rainharvesting.com.au /knowledgecenter/ reasons-for-using-rainwater (August 2016)

4. Information from http://www.bmkg.go.id/BMKG Pusat/Kualitas_Udara/Informasi_Kimia_Air_Hujan. bmkg (August 2016)

5. Information from http://www.lenntech.com/ applications/ultrapure/conductivity/water-conduct ivity.htm (November 2016)

6. Information from http://water.usgs.gov/edu/ph.html (November 2016)

7. Information from http://www.waterresearch.net/index.php/water-treatment/tools/totaldissolved-solids (November 2016)

8. S. Syafalni, Meilani, O. Setyandito, F. Han Yang, IJAES, 9, 1811-1826 (2014)

9. G.B. Gholikandi, M.M. Baneshi, E. Dehghanifara, S. Salehi, A.R. Yari, IJOT, 3, 302-310 (2010)

10. Information from http://www.hc-sc.gc.ca/ewhsemt/pubs/water-eau/devices-dispositifs-eng.php (November 2016)

11. Information from http://www.randwater.co.z a/waterandinfastructuremanagement/pages/waterpur ification.aspx (November 2016)

12. S. Syafalni, I. Abustan, I. Dahlan, K.W. Chan, G. Umar, MAS, 6, 37-51 (2012)

13. S. Syafalni, I. Abustan, A. Brahmana, S.N.F Zakaria, R. Abdullah, MAS, 7, 39-49 (2013)

14. G.G. Malau, Perbaikan Kualitas Air Hujan Untuk Air Minum (Menggunakan Karbon Aktif, Batu Kapur Alami, Batu Kapur yang Dipanaskan 400 C dan Zeolite), Bachelor Thesis (Bina Nusantara University, 2014)

15. Y. Sentoso, Perbaikan Kualitas Air Hujan Menggunakan Karbon Aktif, Batu Bata,Limestone dan Zeolit untuk Air Minum, Bachelor Thesis (Bina Nusantara University, 2014) 